\title{
Combinatorial incorporation of fluoride and cobalt ions into calcium phosphates to stimulate osteogenesis and angiogenesis
}

Citation for published version (APA):

Birgani, Z. T., Gharraee, N., Malhotra, A., van Blitterswijk, C. A., \& Habibovic, P. (2016). Combinatorial incorporation of fluoride and cobalt ions into calcium phosphates to stimulate osteogenesis and angiogenesis. Biomedical Materials, 11(1), [015020]. https://doi.org/10.1088/1748-6041/11/1/015020

Document status and date:

Published: 01/02/2016

DOI:

10.1088/1748-6041/11/1/015020

Document Version:

Publisher's PDF, also known as Version of record

Document license:

Taverne

Please check the document version of this publication:

- A submitted manuscript is the version of the article upon submission and before peer-review. There can be important differences between the submitted version and the official published version of record.

People interested in the research are advised to contact the author for the final version of the publication, or visit the DOI to the publisher's website.

- The final author version and the galley proof are versions of the publication after peer review.

- The final published version features the final layout of the paper including the volume, issue and page numbers.

Link to publication

\footnotetext{
General rights rights.

- You may freely distribute the URL identifying the publication in the public portal. please follow below link for the End User Agreement:

www.umlib.nl/taverne-license

Take down policy

If you believe that this document breaches copyright please contact us at:

repository@maastrichtuniversity.nl

providing details and we will investigate your claim.
}

Copyright and moral rights for the publications made accessible in the public portal are retained by the authors and/or other copyright owners and it is a condition of accessing publications that users recognise and abide by the legal requirements associated with these

- Users may download and print one copy of any publication from the public portal for the purpose of private study or research.

- You may not further distribute the material or use it for any profit-making activity or commercial gain

If the publication is distributed under the terms of Article $25 \mathrm{fa}$ of the Dutch Copyright Act, indicated by the "Taverne" license above, 
PAPER

\section{Combinatorial incorporation of fluoride and cobalt ions into calcium phosphates to stimulate osteogenesis and angiogenesis}

To cite this article: Zeinab Tahmasebi Birgani et al 2016 Biomed. Mater. 11015020

View the article online for updates and enhancements.
Related content

- Toward mimicking the bone structure:
$\frac{\text { design of novel hierarchical scaffolds with }}{\text { a tailored radial porosity gradient }}$
Andrea Di Luca, Alessia Longoni,
Giuseppe Criscenti et al.
- Surface modification of electrospun fibre
$\frac{\text { meshes by oxygen plasma for bone }}{\text { regeneration }}$
A Nandakumar, Z Tahmasebi Birgani, D
Santos et al.
- Improvement of cellular responses of
$\frac{\text { genipin cross-linked chitosan/nano -TCP }}{\text { composite scaffolds by surface }}$
$\frac{\text { modification with fibrin }}{\text { N Siddiqui and K Pramanik }}$

Recent citations

- Biological Roles and Delivery Strategies
$\frac{\text { for lons to Promote Osteogenic Induction }}{\text { Elia Bosch-Rué et al }}$
- $\frac{\text { Characterisation of osteogenic and }}{\frac{\text { vascular responses of hMSCs to Ti-Co }}{\text { doped phosphate glass microspheres }}}$
$\frac{\text { using a microfluidic perfusion platform }}{\text { Carlotta Peticone et al }}$
- Manuel Pedro Fernandes Graca and Sílvia
Rodrigues Gavinho




\title{
Biomedical Materials
}

\section{PAPER}

\section{Combinatorial incorporation of fluoride and cobalt ions into calcium phosphates to stimulate osteogenesis and angiogenesis}

RECEIVED
3 September 2015 REVISED

9 December 2015

ACCEPTED FOR PUBLICATION

21 December 2015

PUBLISHED

29 February 2016

\author{
Zeinab Tahmasebi Birgani ${ }^{1}$, Nazli Gharraee ${ }^{1}$, Angad Malhotra ${ }^{1,2}$, Clemens A van Blitterswijk ${ }^{1,2}$ \\ and Pamela Habibovic ${ }^{1,2}$ \\ 1 Department of Tissue Regeneration, MIRA Institute for Biomedical Technology and Technical Medicine, University of Twente, \\ P.O. Box 217, 7500 AE, Enschede, The Netherlands \\ 2 MERLN Institute for Technology-Inspired Regenerative Medicine, Maastricht University, P.O. Box 616, 6200 MD, Maastricht, \\ The Netherlands \\ E-mail:p.habibovic@maastrichtuniversity.nl
}

Keywords: bone graft substitute, bioinorganic, calcium phosphate, osteogenesis, angiogenesis, human mesenchymal stromal cell, bone

\begin{abstract}
Bone healing requires two critical mechanisms, angiogenesis and osteogenesis. In order to improve bone graft substitutes, both mechanisms should be addressed simultaneously. While the individual effects of various bioinorganics have been studied, an understanding of the combinatorial effects is lacking. Cobalt and fluoride ions, in appropriate concentrations, are known to individually favor the vascularization and mineralization processes, respectively. This study investigated the potential of using a combination of fluoride and cobalt ions to simultaneously promote osteogenesis and angiogenesis in human mesenchymal stromal cells (hMSCs). Using a two-step biomimetic method, wells of tissue culture plates were coated with a calcium phosphate $(\mathrm{CaP})$ layer without or with the incorporation of cobalt, fluoride, or both. In parallel, hMSCs were cultured on uncoated well plates, and cultured with cobalt and/or fluoride ions within the media. The results revealed that cobalt ions increased the expression of angiogenic markers, with the effects being stronger when the ions were added as a dissolved salt in cell medium as compared to incorporation into CaP. Cobalt ions generally suppressed the ALP activity, the expression of osteogenic genes, and the level of mineralization, regardless of delivery method. Fluoride ions, individually or in combination with cobalt, significantly increased the expression of many of the selected osteogenic markers, as well as mineral deposition. This study demonstrates an approach to simultaneously target the two essential mechanisms in bone healing: angiogenesis and osteogenesis. The incorporation of cobalt and fluoride into CaPs is a promising method to improve the biological performance of fully synthetic bone graft substitutes.
\end{abstract}

\section{Introduction}

Approximately 69 weight $\%$ of bone is comprised of mineral that is a calcium phosphate $(\mathrm{CaP})$ in the form of $\mathrm{AB}$ type carbonated apatite [1]. Inspired by this bone composition, CaP-based materials have been successfully used as synthetic bone graft substitutes, and for improving the performance of orthopedic implants [2]. In addition to $\mathrm{CaP}$, the inorganic component of bone contains a number of elements in trace quantities, such as magnesium $\left(\mathrm{Mg}^{2+}\right)$, strontium $\left(\mathrm{Sr}^{2+}\right)$, copper $\left(\mathrm{Cu}^{2+}\right)$, fluoride $\left(\mathrm{F}^{-}\right)$, etc $[1,3]$. While these elements are known to play vital roles in bone healing, formation, and remodeling $[4,5]$, their clinical use is often the result of serendipity, observations based on nutritional deficiencies, or genetic disorders [5]. In comparison to growth factors and other biologics, the advantage of such compounds is their stability, while being relatively inexpensive. Further research is needed to explore the possibilities of these compounds when incorporated into bone graft substitutes.

Several studies have demonstrated that the introduction of relevant bioinorganics to bone graft substitutes may change not only chemistry, but also other properties such as crystallinity, degradation and mechanical properties, thereby also influencing the biological response. More recently, mechanistic studies have shed light into how these elements function individually by altering osteogenesis and bone formation, as summarized in previous review papers [2,4-7]. However, it is not clear what effect the combinations of bioinorganics have on bone regeneration, and how these combinations may affect the overall biological response to bone graft substitutes. Therefore, this 
study was designed to assess the combinatorial effects of two types of bioinorganics, being cobalt $\left(\mathrm{Co}^{2+}\right)$ and fluoride $\left(\mathrm{F}^{-}\right)$ions, on the osteogenic and angiogenic differentiation of human mesenchymal stromal cells (hMSCs).

Being an integral component of vitamin B12 complex and involved in the production of red blood cells, the $\mathrm{Co}^{2+}$ ion is an essential element in physiological mechanisms in humans and other mammals [7, 8]. As a main component of cobalt-chromium metal alloys, cobalt has been commonly used in several orthopedic applications such as total joint replacement and dentistry castings [9]. While cobalt-based alloys offer a high corrosion resistance, chemical stability and excellent mechanical properties [9], there are issues related to the toxicity resulting from wear debris and elevated levels of soluble $\mathrm{Co}^{2+}$ ions $[2,10] . \mathrm{Co}^{2+}$ ion supplementation has been shown to substantially reduce the viability of osteoblastic cells $[11,12]$, and was reported to reduce the expression of osteogenic makers, such as alkaline phosphatase (ALP) and other markers of osteogenesis $[11,13,14] . \mathrm{Co}^{2+}$ ions, in solution or incorporated into $\mathrm{CaP}$, have been shown to activate and increase osteoclast cell differentiation, which may, in part, explain the aseptic loosening of cobalt-based implants in vivo [15]. At higher concentrations $(>10 \mu \mathrm{M})$, however, $\mathrm{Co}^{2+}$ ions may result in a reduction in osteoclast cell number and resorption activity [11].

Several mechanisms have been proposed to describe the toxic effects of $\mathrm{Co}^{2+}$ at higher concentrations, including oxidative damage to DNA, proteins and lipids, putative inhibition of $\mathrm{Ca}^{2+}$ entry and $\mathrm{Ca}^{2+}$-signaling, competition with $\mathrm{Ca}^{2+}$ for intracellular binding to proteins and inhibition of activity of crucial enzymes [10].

There is evidence that $\mathrm{Co}^{2+}$ ions, by inducing hypoxia conditions [16], increase expression of angiogenic genes and proteins such as vascular endothelial growth factor (VEGF) [14, 17]. It has been also shown that the addition of $\mathrm{Co}^{2+}$ ions and cells treated with $\mathrm{Co}^{2+}$ ions to tissue engineered scaffolds promotes neovascularization in animal models, which, contrary to in vitro results mentioned above, may indirectly benefit in vivo bone formation $[12,17]$. Therefore, combining $\mathrm{Co}^{2+}$ ions with factors, which directly promote expression of osteogenic markers, may be a promising strategy for inducing formation of vascularized bone.

Fluoride $\left(\mathrm{F}^{-}\right)$has been recognized as an essential element in mineralized tissues, including bone and teeth $[4,18]$, with the use of fluoride as an additive in the formulation of toothpaste being an example of the daily use of bioinorganics $[5,19]$. While $\mathrm{F}^{-}$ions in the form of sodium fluoride has been used clinically for the treatment of osteoporosis [4], in vitro results have shown a dose-dependent effect of $\mathrm{F}^{-}$ions on proliferation and osteogenic differentiation of various relevant cell types [20-22]. These results revealed that doses lower than $100 \mu \mathrm{M}$ promoted osteogenic differentiation and osteoblast proliferation, whereas doses higher than $500 \mu \mathrm{M}$ induced apoptosis and inhibition of oste- ogenic markers [21]. Moreover, sodium fluoride has been reported to be involved in the initiation of osteogenesis from the embryonic mesenchyme, and in the formation of a bone-like matrix [22].

As with other bioinorganics, the incorporation of $\mathrm{F}^{-}$ions into synthetic bone graft substitutes has been previously explored, especially in association with $\mathrm{CaPs}$ and bioactive glasses [23-30]. This incorporation of $\mathrm{F}^{-}$ions has been shown to promote the proliferation and osteogenic differentiation of different cell types, with the cell response being substantially dependent on the fluoride concentration, the substrate material and cell source [25-33]. In addition to these biological effects, many studies have demonstrated significant changes in the biomaterial's physicochemical properties, including crystallinity, dissolution rate, mechanical properties and coating-substrate adhesion when $\mathrm{F}^{-}$was incorporated into CaPs [23-27].

While both $\mathrm{Co}^{2+}$ and $\mathrm{F}^{-}$ions individually have beneficial effects that can promote bone healing, their use in combination needs greater investigation in order to develop improved bone graft substitutes with the ability to simultaneously induce osteogenic and angiogenic responses. This study was set up in such a way. Firstly, the effect of $\mathrm{Co}^{2+}$ ions on the expression of angiogenic markers was investigated. Secondly, $\mathrm{F}^{-}$ions were added and proliferation and osteogenic differentiation was studied and compared to the sole effects of fluoride and cobalt ions. This was done in order to investigate whether the presence of $\mathrm{Co}^{2+}$ ions would compromise the effect of $\mathrm{F}^{-}$ions on the proliferation and osteogenic differentiation of hMSC.

\section{Materials and methods}

\section{Preparation of $\mathrm{Co}^{2+}$ and $\mathrm{F}^{-}$stock solutions}

A Tris buffer solution was prepared by dissolving $6.05 \mathrm{~g}$ Tris base (Sigma), $41 \mathrm{ml} 1 \mathrm{M} \mathrm{HCl}$ (Sigma) in pure MilliQ water to a total volume of $11(\mathrm{pH}=7.4)$ as was previously described $[15,32] . \mathrm{Co}^{2+}$ and $\mathrm{F}^{-}$stock solutions were prepared by dissolving appropriate amounts of $\mathrm{CoCl}_{2}$ (Sigma) and $\mathrm{NaF}$ (Sigma) salts in Tris buffer to reach the concentration of $10 \mathrm{mM}$ and $100 \mathrm{mM}$ of $\mathrm{Co}^{2+}$ and $\mathrm{F}^{-}$, respectively, representing a low and high dose. For sterilization, the stock solutions were filtered using $0.22 \mu \mathrm{M}$ filters and kept at $4{ }^{\circ} \mathrm{C}$.

\section{Coating preparation}

The CaP coatings were deposited on the surface of treated tissue culture 24- well plates (Nunc). The deposition of $\mathrm{CaP}$ coating was achieved via a 2-step biomimetic coating approach, which has been previously described $[15,32]$. Briefly, in the first step, a concentrated simulated body fluid solution (SBF $2.5 \mathrm{x})$ was prepared with ionic content of $733.5 \mathrm{mM}$ $\mathrm{Na}^{+}, 7.5 \mathrm{mM} \mathrm{Mg}^{2+}, 12.5 \mathrm{mM} \mathrm{Ca}^{2+}, 720 \mathrm{mM} \mathrm{Cl}^{-}$, $5 \mathrm{mM} \mathrm{HPO}_{4}^{2-}$ and $21 \mathrm{mM} \mathrm{HCO}_{3}^{-} .1 \mathrm{ml}$ of SBF $2.5 \mathrm{X}$ was added to each well, and refreshed daily, for three days at room temperature. In the second step, a calcium 
Table 1. An overview of samples with $\mathrm{Co}^{2+}$ and/or $\mathrm{F}^{-}$ion concentrations in cell culture medium and in the CaP solution used for coating preparation.

\begin{tabular}{|c|c|c|c|}
\hline & Sample label & $\begin{array}{l}\text { Concentration of } \mathrm{Co}^{2+} \text { in cell } \\
\text { medium }(\mu \mathrm{M})\end{array}$ & $\begin{array}{l}\text { Concentration of } \mathrm{F}^{-} \text {in } \\
\text { cell medium }(\mu \mathrm{M})\end{array}$ \\
\hline \multirow[t]{7}{*}{ Ions directly supplemented to the medium } & Co 0 & 0 & 0 \\
\hline & Co 0.1 & 0.1 & 0 \\
\hline & Co 20 & 20 & 0 \\
\hline & F 1000 & 0 & 1000 \\
\hline & F1000 Co 0.1 & 0.1 & 1000 \\
\hline & F1000 Co 20 & 20 & 1000 \\
\hline & Sample label & $\begin{array}{l}\text { Concentration of } \mathrm{Co}^{2+} \text { in } \\
\text { CPS solution }(\mu \mathrm{M})\end{array}$ & $\begin{array}{l}\text { Concentration of } \mathrm{F}^{-} \text {in } \\
\text { CPS solution }(\mu \mathrm{M})\end{array}$ \\
\hline \multirow[t]{6}{*}{ Ions incorporated into $\mathrm{CaP}$ coatings } & Co 0 & 0 & 0 \\
\hline & Co 0.1 & 0.1 & 0 \\
\hline & Co 20 & 20 & 0 \\
\hline & F 1000 & 0 & 1000 \\
\hline & F1000 Co 0.1 & 0.1 & 1000 \\
\hline & F1000 Co 20 & 20 & 1000 \\
\hline
\end{tabular}

phosphate solution (CPS) was prepared consisting of $140 \mathrm{mM} \mathrm{Na}^{2+}, 4 \mathrm{mM} \mathrm{Ca}^{2+}, 2 \mathrm{mM} \mathrm{HPO}_{4}^{2-}$ and $144 \mathrm{mM}$ $\mathrm{Cl}^{-}$(buffered at $\mathrm{pH}$ 7.4). Appropriate volumes of $\mathrm{Co}^{2+}$ and $\mathrm{F}^{-}$stock solutions were added to the CPS solution to reach the desired concentrations of ions in the CPS solutions (table 1). According to the groups, $1 \mathrm{ml}$ of the CPS solution with varying concentrations of ions was added to each well, and refreshed daily, for three days at room temperature. The coatings were then washed three times with demineralized water and dried overnight in an air oven.

\section{Coating characterization}

The chemistry of the mineral phase was characterized by Fourier transform infrared spectroscopy (FTIR, Perkin-Elmer Spectrum 1000) and x-ray diffraction (XRD, Miniflex, Rigaku).

The morphology of the mineral films was characterized using scanning electron microscopy (SEM, XL-30 ESEM-FEG, Philips) in the secondary electron mode, coupled with an energy dispersive $\mathrm{x}$-ray spectroscopy analyzer (EDS, EDAX, AMETEK Materials Analysis Division) at the accelerator voltage of $10 \mathrm{KeV}$ and working distance of $10 \mathrm{~mm}$. The samples were sputtered with a thin gold layer prior to imaging. Quantification of the EDS data was achieved using the TEAM ${ }^{\mathrm{TM}}$ EDS V2.2 software provided by the EDS manufacturer.

\section{Cell subculture}

Human mesenchymal stromal cells (hMSCs) were isolated from bone marrow aspirates $(5-20 \mathrm{ml})$ obtained from one donor with written informed consent $[34,35]$. Aspirates were resuspended using $20 \mathrm{G}$ needles, plated at a density of $5 \times 10^{5}$ cells per $\mathrm{cm}^{2}$, and cultured in proliferation medium (consisting of $\alpha$-MEM (Gibco) supplemented with $10 \%$ fetal bovine serum (Lonza), 2 mM L-glutamine (Gibco), $0.2 \mathrm{mM}$ ascorbic acid (Sigma), $100 \mathrm{U} \mathrm{ml}^{-1}$ penicillin and $100 \mu \mathrm{g} \mathrm{ml}^{-1}$ streptomycin (Gibco) and $1 \mathrm{ng} \mathrm{ml}^{-1}$ rhbFGF (AbDSerotec)). The medium was refreshed every $2-3 \mathrm{~d}$. The cells were harvested using the standard trypsinization method at approximately $80 \%$ confluency for subculture until passage 3 .

\section{Cell culture}

$\mathrm{CaP}$ coatings were sterilized with ethanol prior to cell culture. To sterilize, the CaP-coated wells were washed three times with $70 \%$ ethanol followed by $15 \mathrm{~min}$ of drying inside the flow cabinet after each washing step. In the last step of sterilization, $100 \%$ ethanol was added to the samples and allowed to evaporate in the flow cabinet for at least $2 \mathrm{~h}$. The wells were then washed twice with sterile PBS. $1 \mathrm{ml}$ of basic medium ( $\alpha$-MEM (Gibco) supplemented with 10\% fetal bovine serum (Lonza), $2 \mathrm{mM}$ L-glutamine (Gibco), $0.2 \mathrm{mM}$ ascorbic acid (Sigma), $100 \mathrm{Uml}^{-1}$ penicillin and $100 \mu \mathrm{g} \mathrm{ml}^{-1}$ streptomycin (Gibco)) was added to each sterilized sample, and then incubated overnight in a $5 \% \mathrm{CO}_{2}$ humid atmosphere at $37^{\circ} \mathrm{C}$.

hMSCs $(n=3)$ were cultured on the coated plates for the analysis of DNA amounts, ALP activity, the expression of a set of osteogenic markers on mRNA level and mineralization. For mineralization assessment in the trans-well set-up $n=2$ was used as a sample size. All the measurements were performed twice on the same set of samples.

hMSCs of passage 3 were seeded on treated tissue culture plates (TCPs) with and without $\mathrm{CaP}$ coatings at a density of 10000 cells $\mathrm{cm}^{-2}$ in approximately $50 \mu \mathrm{l}$ of basic medium. $2 \mathrm{ml}$ of either basic, osteogenic (basic medium supplemented with $10 \mathrm{nM}$ dexamethasone (Sigma)) or mineralization medium (osteogenic medium supplemented with $0.01 \mathrm{M}$ $\beta$-glycerophosphate (Sigma)) was directly added to each treated well with and without $\mathrm{CaP}$ coating. Appropriate volumes of ion stock solutions were also added 
Table 2. Primer sequence of the angiogenic and osteogenic genes investigated.

\begin{tabular}{|c|c|}
\hline Gene & Primer sequence \\
\hline \multirow[t]{2}{*}{ GAPDH (housekeeping gene) } & 5'-CCATGGTGTCTGAGCGATGT \\
\hline & 5'-CCATGGTGTCTGAGCGATGT \\
\hline \multirow[t]{2}{*}{ Vascular endothelial growth factor (VEGF) } & 5'-AGGTCTCGATTGGATGGCA \\
\hline & 5'-AGGGCAGAATCATCACGAAGT \\
\hline \multirow[t]{2}{*}{ CD31 } & 5'-GAACGGTGTCTTCAGGTTGGTATTTCA \\
\hline & 5'-TCTATGACCTCGCCCTCCACAAA \\
\hline \multirow[t]{2}{*}{ Alkaline phosphatase (ALP) } & 5'-TTCAGCTCGTACTGCATGTC \\
\hline & 5'-ACAAGCACTCССАСТTCATC \\
\hline \multirow[t]{2}{*}{ Bone sialoprotein (BSP) } & 5'-TCCCGTTCTCACTTTCATA \\
\hline & 5'-CCCCACCTTTTGGGAAAAC \\
\hline \multirow[t]{2}{*}{ Bone morphogenetic protein 2 (BMP2) } & 5'-GCATCTGTTCTCGGAAAACCT \\
\hline & 5'-ACTACCAGAAACGAGTGGGAA \\
\hline \multirow[t]{2}{*}{ Osteocalcin (OC) } & 5'-CGCCTGGGTCTCTTCACTAC \\
\hline & 5'-TGAGAGCCCTCACACTCCTC \\
\hline \multirow[t]{2}{*}{ Osteopontin (OP) } & 5'-CCAAGTAAGTCCAACGAAAG \\
\hline & 5'-GGTGATGTCCTCGTCTGTA \\
\hline
\end{tabular}

to each well without $\mathrm{CaP}$ coating to reach $\mathrm{Co}^{2+}$ concentrations of $0,0.1$ and $20 \mu \mathrm{M}$, and $\mathrm{F}^{-}$concentrations of 0 and $1000 \mu \mathrm{M}$ in cell culture mediums (table 1.). The medium was refreshed every $2-3 \mathrm{~d}$.

A parallel cell culture in a trans-well set up was performed to investigate the mineralization of hMSCs when exposed to ion-incorporated $\mathrm{CaP}$ coatings. Glass coverslips were coated with $\mathrm{Co}^{2+}$ and $\mathrm{F}^{-}$-incorporated $\mathrm{CaP}$ coatings using the method described above. The coated coverslips were then sterilized, and conditioned overnight in basic medium similar to the coated well plates. hMSCs were cultured on the bottom compartment of trans-wells in either basic or mineralization medium. The CaP-coated coverslips were placed in the top compartment of trans-wells, sharing the medium with cells. The medium was refreshed every $2-3 \mathrm{~d}$.

\section{DNA content and ALP activity quantification}

Total DNA was assessed with CyQuant Cell Proliferation Assay kit (Invitrogen) at days 7 and 14. After 3 cycles of freeze/thaw at $-80^{\circ} \mathrm{C}, 500 \mu \mathrm{l}$ lysis buffer (lysis buffer provided in the kit diluted in a buffer of $\mathrm{NaCl}$-EDTA solution) was added to each well. The samples were ultra-sonicated and incubated at room temperature for $1 \mathrm{~h}$. After centrifugation, the lysis buffer was collected and the DNA content was measured in accordance with manufacturer's protocol. Briefly, $100 \mu \mathrm{l}$ of the supernatant was mixed with the same volume of CyQuant GR dye in a 96 well micro-plate and incubated for $15 \mathrm{~min}$. Fluorescence measurements for DNA quantification were done at excitation and emission wavelengths of 480 and $520 \mathrm{~nm}$, respectively, using a spectrophotometer (Perkin Elmer). ALP activity of the cells was measured using a CDP-star kit (Roche Applied Science) at days 7 and $14.10 \mu \mathrm{l}$ of the lysis buffer used for quantifying DNA content was mixed with $40 \mu \mathrm{l} \mathrm{CDP-}$ star reagent in a 96 well micro-plate and incubated for $30 \mathrm{~min}$. After incubation, chemiluminescence measurements were completed at $466 \mathrm{~nm}$. Results of the DNA assays are presented based on average $\mu \mathrm{g}$ of DNA detected in each condition normalized for DNA content of hMSCs cultured on TCPs in basic medium without ion addition for $7 \mathrm{~d}$. Results of ALP activity were normalized per DNA content of each culture and ALP activity of hMSCs cultured on TCPs in basic medium without ion addition for $7 \mathrm{~d}$ and presented as the average of normalized ALP activity.

\section{RNA extraction and gene expression (qPCR) assay}

Total RNA was isolated by using a NucleoSpin ${ }^{\circledR}$ RNA II isolation kit (Macherey Nagel) for cells cultured on TCPs and in combination with NucleoSpin ${ }^{\circledR}$ RNA II isolation kit and Trizol method for cells cultured on CaP coatings, in accordance with the manufacturer's protocol at days 7 and 14. RNA was collected in RNAse-free water and the total concentration was measured using nano-drop measurement equipment (ND1000 spectrophotomer, Thermo Scientific). The cDNA of the cultures were then prepared using an iScript kit (Bio-Rad) according to the manufacturer's protocol and diluted 10 times in RNAse-free water to be used for quantitative real-time PCR (qPCR). The qPCR measurements were completed using Bio-Rad equipment using Syber green I master mix (Invitrogen) and the primers (Sigma) the sequences of which are listed in table 2. Expression of the osteogenic marker genes were normalized to GAPDH levels and hMSCs cultured on TCPs in basic medium for $7 \mathrm{~d}$, and the fold inductions were calculated by using the $\Delta \Delta \mathrm{CT}$ method

\section{Mineralization assay}

Alizarin Red staining was done at day 21 in order to investigate the mineralization of hMSCs. The cultures were washed twice with PBS after aspirating the medium, fixed with $4 \%$ paraformaldehyde (PFA) (Sigma) in phosphate buffered saline (PBS), buffered 
at $\mathrm{pH} 7.4$ for $30 \mathrm{~min}$ and washed at least twice with PBS. The cells were stained with 2\% Alizarin red solution (Sigma) for $5 \mathrm{~min}$, washed with PBS and imaged using a stereomicroscope (SMZ-10A, Nikon).

In order to quantify the mineralization of hMSCs, $200 \mu \mathrm{L}$ of $1 \mathrm{M} \mathrm{HCl}$ (Sigma) was added to each well and collected after $1 \mathrm{~min}$. The calcium content in the acid was then quantified using QuantiChrom ${ }^{\mathrm{TM}}$ calcium assay kit (BioAssay Systems) according to manufacturer's protocol. A spectrophotometric plate-reader (Thermo Scientific MultiscanGo) was used to read the optical density of calcium complexes at $612 \mathrm{~nm}$.

\section{Statistical analysis}

Statistical comparisons were performed using One-way Analysis of Variance (ANOVA) followed by a Tukey's multiple comparison test. For all analyses, the following p-value applies: $* p<0.05$.

\section{Results}

\section{Coating characterization}

To analyze the morphology and chemical composition of the different coatings, SEM imaging and EDS elemental analysis were performed, respectively (figures 1 (a1) - (f1)). A homogenous crystalline mineral layer composed of globules with a diameter of approximately $5 \mu \mathrm{m}$, was observed in all conditions. The crystals of $\mathrm{CaP}$ coatings without additives exhibited a flat platelike morphology oriented perpendicular to the surface of the substrate (figure 1(a2)). The presence of $\mathrm{Co}^{2+}$ ions did not alter the morphology of the crystals in the coatings (figures 1(b2)-(c2)). Upon $\mathrm{F}^{-}$incorporation, the size of coating globules did not change, however, instead of a plate-like morphology, the individual crystals exhibited a rod-shaped morphology (figures 1(d2)-(f2)).

EDS spectra of all the coatings showed sharp peaks of calcium, phosphorous and oxygen (figures 1(a3)(f3)), confirming the formation of a CaP layer. Sodium and chlorine peaks were observed in the spectra of $\mathrm{CaP}$ coatings, suggesting incomplete washing. Within the energy range of $0-10 \mathrm{KeV}$, the most intense peak of cobalt appears at $0.776 \mathrm{KeV}$. In the EDS spectra of $\mathrm{CaP}$ and $\mathrm{CaP} \mathrm{Co} 0.1$, such a peak was not observed, whereas, a small peak at approximately $0.7-0.8 \mathrm{KeV}$ was observed in EDS spectrum of CaP Co20. Fluorine peak was observed in all the $\mathrm{CaP}$ coatings with $\mathrm{F}^{-}$incorporation (figures 1(a3)-(f3)).

Semi-quantitative analysis of EDS data (figure $1(\mathrm{~g})$ ) revealed a $\mathrm{Ca} / \mathrm{P}$ ratio of approximately $1.3-1.5$ in all the coatings. The mean Co content of the $\mathrm{CaP}$ coatings without $\mathrm{Co}^{2+}$ incorporation and with low concentration of $\mathrm{Co}^{2+}$ was calculated to be lower than 0.05 atomic percent (at\%), whereas, CaP Co20 and CaP F1000 Co20 coatings contained $0.18 \pm 0.04$ at $\%$ and $0.15 \pm 0.02$ at $\%$ cobalt, respectively. The results of fluorine quantification showed a value of $1.15 \pm 0.02$ at $\%$ for $F$ content in the coatings without $\mathrm{F}^{-}$incorporation, while addition of $1000 \mu \mathrm{M} \mathrm{F}^{-}$to CPS solution resulted in $5.1 \pm 0.66,4.19 \pm 0.95$ and $3.79 \pm 1.06$ at $\%$ fluorine in the CaP F1000, CaP F1000 Co 0.1 and CaP F1000 Co20 coatings, respectively (figure $1(\mathrm{~g})$ ).

The composition of the coating and the effect of ion incorporation on the crystalline structure were further investigated by FTIR and XRD analyses (figure 2). All the FTIR spectra were typical of CaPs prepared using the biomimetic coating method $[36,37]$. The FTIR spectra of all CaP coatings exhibited phosphate peaks at 568,605 and a set of peaks at approximately $1040 \mathrm{~cm}^{-1}$. The small peaks observed at $1410-1450 \mathrm{~cm}^{-1}$ are attributed to carbonate groups, which may be incorporated into the crystalline lattice during coating deposition. Moreover, two small bands appeared at 860 and $910 \mathrm{~cm}^{-1}$, which are typical of $\mathrm{HPO}_{4}^{2-}$ bands in octacalcium phosphate (OCP) structure. The band at approximately $1650 \mathrm{~cm}^{-1}$ represents presence of water. The broad band at approximately $3400 \mathrm{~cm}^{-1}$ also belongs to absorbed $\mathrm{H}_{2} \mathrm{O}$ groups and the small shoulder at $3550 \mathrm{~cm}^{-1}$ represents $\mathrm{OH}^{-}$groups [38]. Addition of $\mathrm{Co}^{2+}$ to CPS solution did not affect the FTIR spectra of $\mathrm{CaP}$ coatings. However, upon $\mathrm{F}^{-}$incorporation, the $\mathrm{HPO}_{4}^{2-}$ peak at $910 \mathrm{~cm}^{-1}$ disappeared and the intensity of the $\mathrm{HPO}_{4}^{2-}$ peak at $860 \mathrm{~cm}^{-1}$ was reduced. Moreover, the $\mathrm{OH}^{-}$peak at $3550 \mathrm{~cm}^{-1}$ disappeared upon addition of $\mathrm{F}^{-}$to the coatings (figure 2(a)).

The XRD patterns of the coatings showed only peaks with very low intensity in the $2 \theta$ range of $5-70^{\circ}$. A larger peak appeared at $5.6^{\circ}$ theta, which may represent the 010 crystalline plane in the OCP structure that is expected at approximately $4^{\circ}$ theta. The less intense peak appearing at $25.7^{\circ}$ theta are also observed in the XRD pattern of $\mathrm{OCP}$ as a less intense peak that is attributed to plane 002 . The small peak observed at approximately $32^{\circ}$ theta is typical for XRD patterns of both apatite and OCP. No substantial changes were observed in the XRD patterns of the $\mathrm{CaP}$ coatings upon addition of $\mathrm{Co}^{2+}$ and $\mathrm{F}^{-}$ions to CPS solution (figure 2(b)).

\section{Effect of $\mathrm{Co}^{2+}$ on the expression of angiogenic genes} The angiogenic effect of $\mathrm{Co}^{2+}$ ions on hMSC was analyzed with qPCR, using VEGF and CD31 as angiogenic markers (figure 3). At day 7 , no significant differences were observed in the expression of VEGF upon addition of $\mathrm{Co}^{2+}$ to basic medium. At day 14 , the addition of $\mathrm{Co}^{2+}$ to basic medium in both concentrations led to a significant increase in the expression of VEGF (figure 3(a1)). A similar trend was observed in the expression of CD31, however, this result was not statistically significant at either time point (figure 3(a2)). Similar to medium conditioning with $\mathrm{Co}^{2+}$ ions, $\mathrm{Co}^{2+}$ ions incorporated into $\mathrm{CaP}$ coatings did not affect the expression of VEGF at mRNA level at day 7. At day 14, a small increase in the expression of VEGF and CD31 was observed in the hMSCs cultured on $\mathrm{CaP} \mathrm{Co} 20$, however, this difference was not statistically significant for either marker (figures 3(b1) and (b2)). 

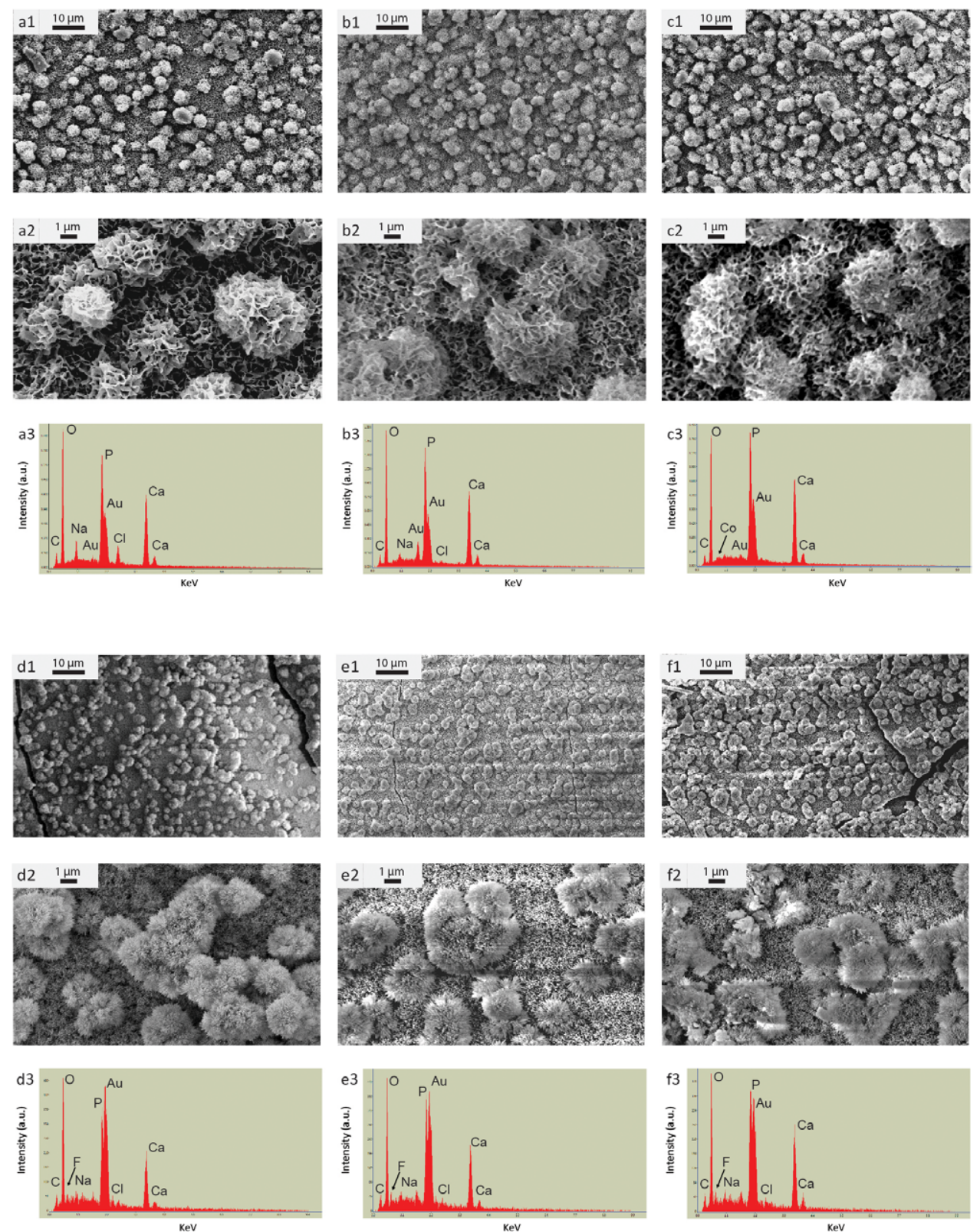

g

\begin{tabular}{lllll}
\hline Sample & Ca & P & Co & F \\
\hline CaP & $21.54 \pm 1.49$ & $15.20 \pm 0.89$ & $0.43 \pm 0.04$ & $1.25 \pm 0.26$ \\
CaP Co 0.1 & $24.37 \pm 4.70$ & $16.53 \pm 1.75$ & $0.01 \pm 0.01$ & $1.00 \pm 0.22$ \\
CaP Co20 & $22.09 \pm 1.30$ & $16.42 \pm 0.80$ & $0.18 \pm 0.04^{*}$ & $1.19 \pm 0.34$ \\
CaP F 1000 & $17.59 \pm 1.43$ & $13.27 \pm 1.00$ & $0.04 \pm 0.02$ & $5.13 \pm 0.66^{*}$ \\
CaP F1000 Co 0.1 & $18.61 \pm 1.32$ & $14.19 \pm 0.61$ & $0.02 \pm 0.00$ & $4.19 \pm 0.95^{*}$ \\
CaP F1000 Co 20 & $25.53 \pm 8.51$ & $16.09 \pm 2.55$ & $0.15 \pm 0.02^{*}$ & $3.79 \pm 1.06^{*}$
\end{tabular}

Figure 1. SEM images at low (a1-f1) and high (a2-f2) magnifications, and EDS spectra (a3-f3) of CaP, CaP Co0.1, CaP Co20, CaP F1000, CaP F1000 Co 0.1 and CaP F1000 Co 20, respectively, and Ca, P, Co and F content (g) in CaP coatings quantified based on EDS analysis. A homogeneous low-crystallinity $\mathrm{CaP}$ layer was formed on the surface of tissue culture well plates. $\mathrm{Co}^{2+}$ and $\mathrm{F}^{-}$content of approximately $0.15-0.18$ at $\%$ and $3.79-5.1$ at $\%$ was detected in the coatings upon addition of $20 \mu \mathrm{M}^{\circ} \mathrm{Co}^{2+}$ and $1000 \mu \mathrm{M}$ of $\mathrm{F}^{-}$to CPS solution, respectively. 
a

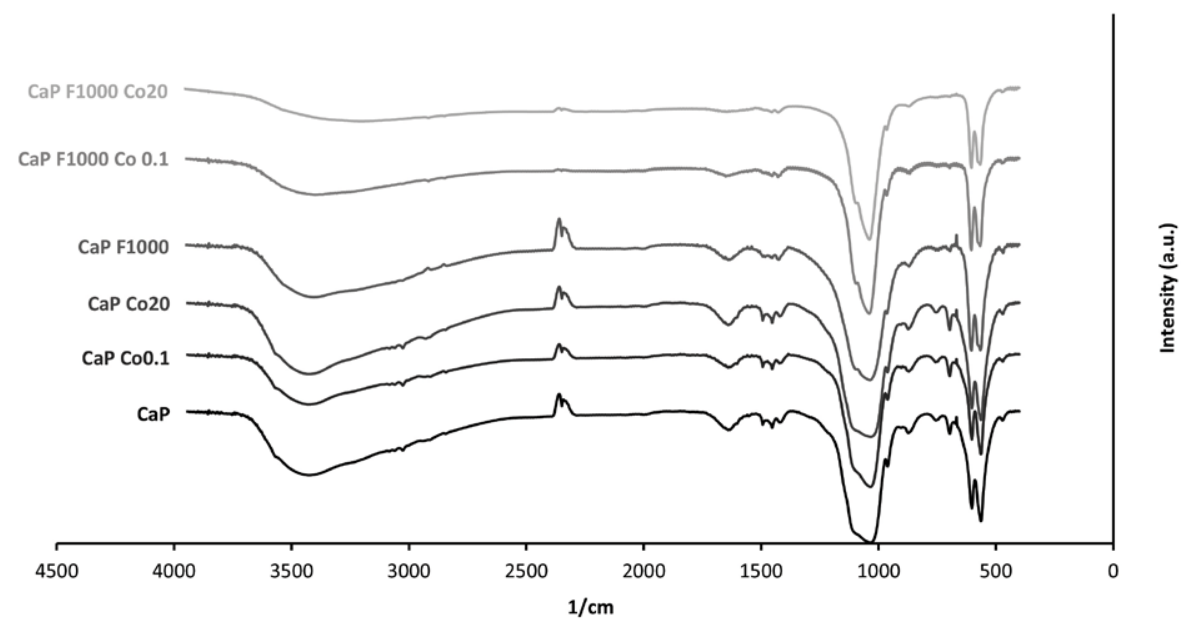

b

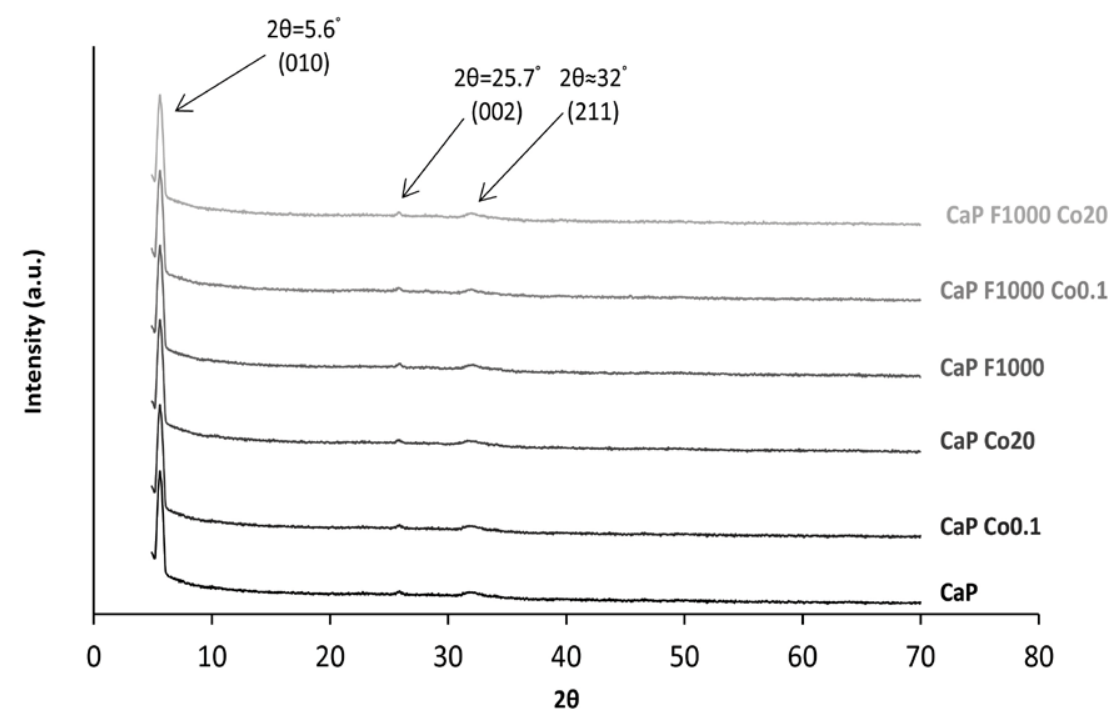

Figure 2. XRD patterns (a) and FTIR spectra (b) of the CaP coatings without and with additives. The XRD patterns and the FTIR spectra suggested that the predominant phase was octacalcium phosphate, with a limited presence of carbonate. Addition of $\mathrm{F}^{-}$ions to the coating solution rendered the $\mathrm{CaP}$ phase more apatitic.

\section{Effect of $\mathrm{Co}^{2+}$ and $\mathrm{F}^{-}$on DNA content}

When added to cell culture medium, $\mathrm{Co}^{2+}$ and $\mathrm{F}^{-}$ ions did not significantly affect the DNA content of hMSCs at day 7. At day 14 in both basic and osteogenic medium, F1000 showed significantly higher DNA content compared to all the other conditions, except F1000 Co0.1 in basic medium. Moreover, hMSCs cultured with $20 \mu \mathrm{M} \mathrm{Co}^{2+}$ showed significantly lower DNA content compared to all conditions containing $\mathrm{F}^{-}$, while no differences were seen with cells cultured in media without additives (figure 4(a1)).

When $\mathrm{Co}^{2+}$ and $\mathrm{F}^{-}$ions were incorporated into $\mathrm{CaP}$ coatings, no significant differences were detected on the DNA content of hMSCs at day 7. At day 14, the incorporation of $\mathrm{F}^{-}$into the $\mathrm{CaP}$ coating in general decreased the DNA content of the cells in both basic and osteogenic media, as compared to the control and coatings with only $\mathrm{Co}^{2+}$, which was in contrast to the findings of conditioned media (figure 4(b1)).

\section{Effect of $\mathrm{Co}^{2+}$ and $\mathrm{F}^{-}$on ALP activity}

Enzymatic ALP activity of hMSCs, as an early marker of osteogenesis, was quantified at days 7 and 14, normalized for DNA content and expressed in relation to the ALP activity in basic medium at $7 \mathrm{~d}$ (figures $4(\mathrm{a} 2)$ - (b2)). ALP levels measured in cells cultured on tissue culture plastic without coating were found to be higher than those measured in cells cultured on CaP coatings, independent of the medium used. The addition of $\mathrm{F}^{-}$ions to cell culture medium (figure 4(a2)) generally increased the ALP activity in hMSCs compared to control sample and samples containing only $\mathrm{Co}^{2+}$ ions, an effect that was independent of cell medium or time point. $\mathrm{Co}^{2+}$ ions, when added individually to cell medium, did not alter the ALP activity at day 7 and reduced the ALP activity at day 14 with a dose-dependent trend. The combination of $\mathrm{F}^{-}$with $\mathrm{Co}^{2+}$ in higher concentration decreased the ALP activity as compared to $\mathrm{F}^{-}$alone, however, this activity was still greater than that measured upon addition of only $\mathrm{Co}^{2+}$. 
a1

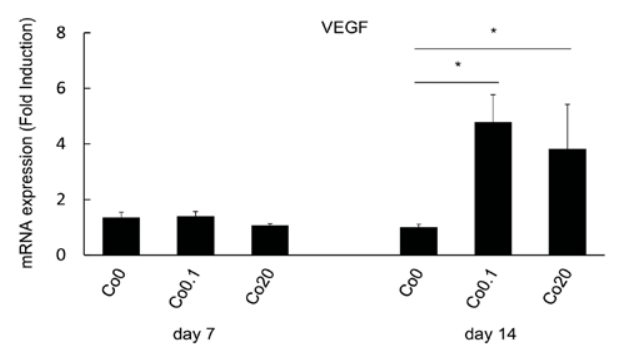

a2

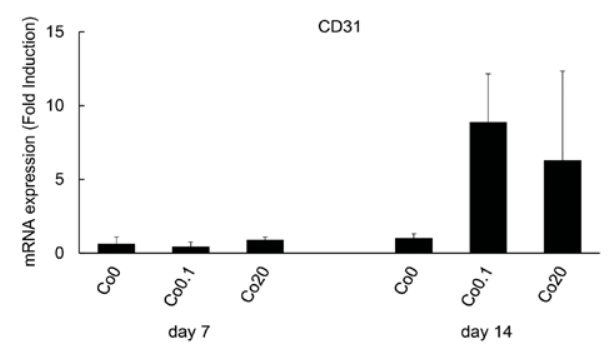

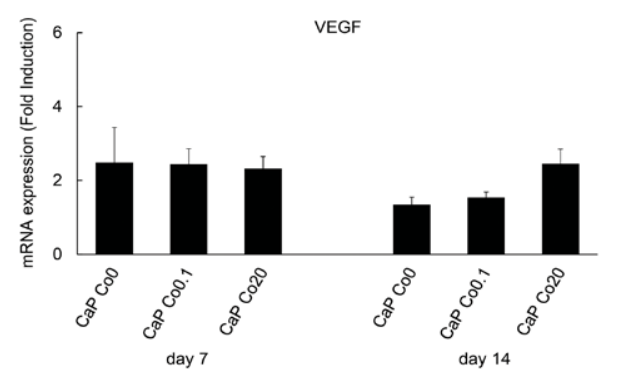

b2

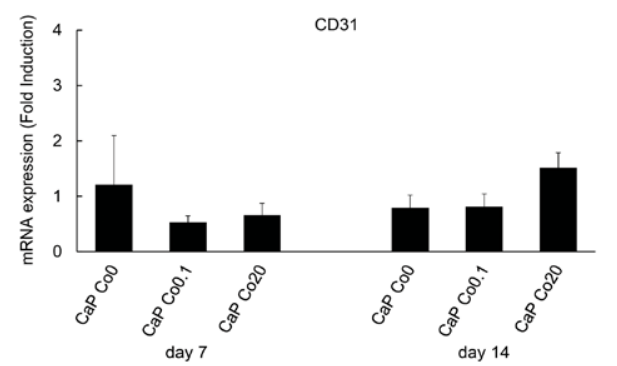

Figure 3. mRNA expression of VEGF (a1,b1) and CD31 (a2,b2) in hMSCs $(n=3)$ cultured on uncoated tissue culture plastic and on CaP coatings, respectively. $\mathrm{Co}^{2+}$ ions increased the expression of both markers after $14 \mathrm{~d}$ culture via both delivery methods with the effects being stronger when the ions were directly added to cell culture medium.

a1

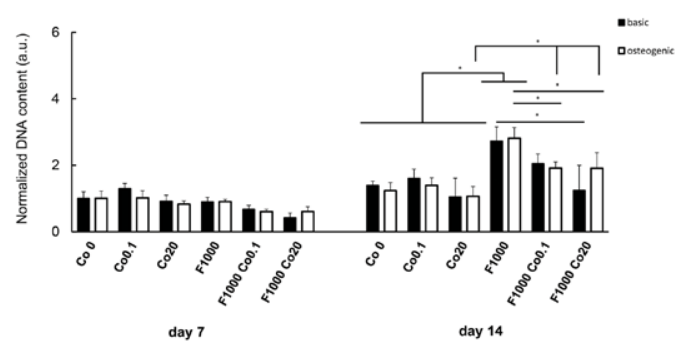

a2

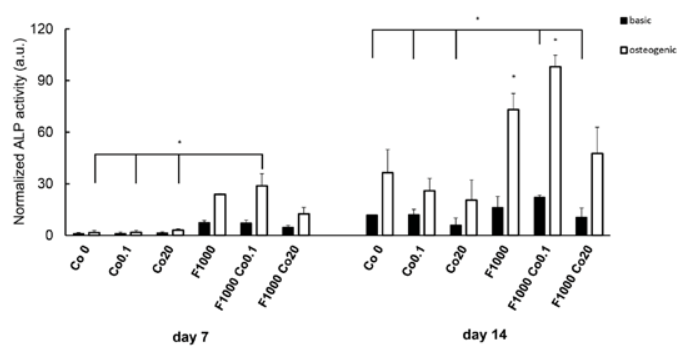

b1

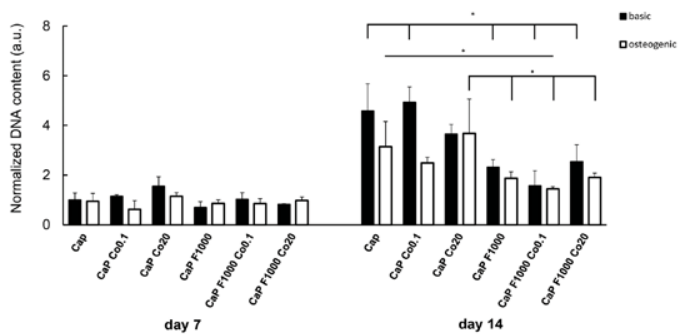

b2

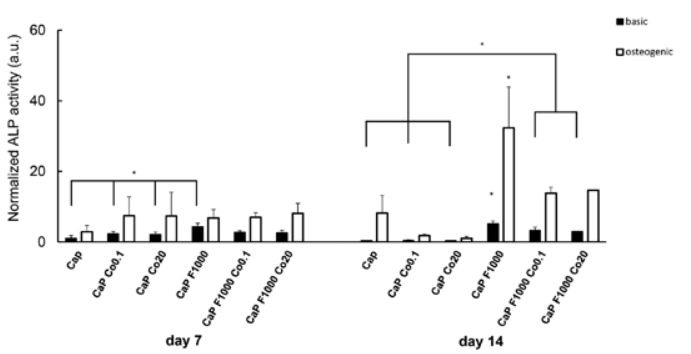

Figure 4. DNA content (a1, b1) and ALP activity (a2, b2) of hMSCs $(n=3)$ cultured on uncoated tissue culture plastic and on CaP coatings, respectively. DNA content of the cells did not change upon exposure to $\mathrm{Co}^{2+}$, whereas $\mathrm{F}^{-}$ions increased the DNA content of the cells at day 14 when added to the medium, and decreased it when incorporated into CaP coatings. While a slight decrease in ALP activity of hMSCs was observed upon exposure to $\mathrm{Co}^{2+}, \mathrm{F}^{-}$ions favored the expression of ALP activity.

In the CaP group, at day 7, the cells cultured in basic media on CaP F1000 had significantly higher ALP activity than the ones cultured of $\mathrm{CaP}, \mathrm{CaP} \mathrm{Co} 0.1$ and CaP Co20 (figure 4(b2)), though the differences were relatively small. At day 14 , a general observation was that ALP activity in all the $\mathrm{F}^{-}$-incorporated samples was higher than the one quantified in $\mathrm{CaP}, \mathrm{CaP} \mathrm{Co} 0.1$ and $\mathrm{CaP} \mathrm{Co} 20$, independent of medium type, with $\mathrm{CaP}$ F1000 always resulting in highest ALP activity. Individual incorporation of $\mathrm{Co}^{2+}$, however, reduced the ALP activity independent of cell medium. In combination with $\mathrm{F}^{-}$incorporation, $\mathrm{Co}^{2+}$ incorporation also resulted in a reduction in ALP activity, however, in this case, the ALP activity was still higher than the one in $\mathrm{CaP}$ coatings without ion incorporation and with only $\mathrm{Co}^{2+}$ incorporation.

\section{Effect of $\mathrm{Co}^{2+}$ and $\mathrm{F}^{-}$on expression of osteogenic genes}

Expression of osteogenic markers including ALP, BSP, BMP2, OC and OP of hMSCs in ions-conditioned media and upon culture on coatings incorporating ions 
a1

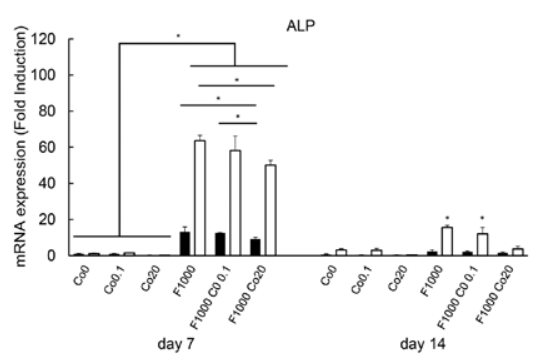

a2

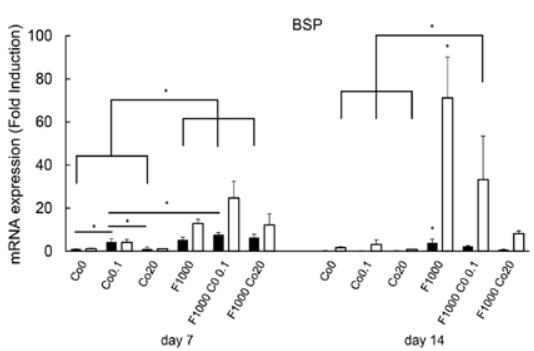

a3

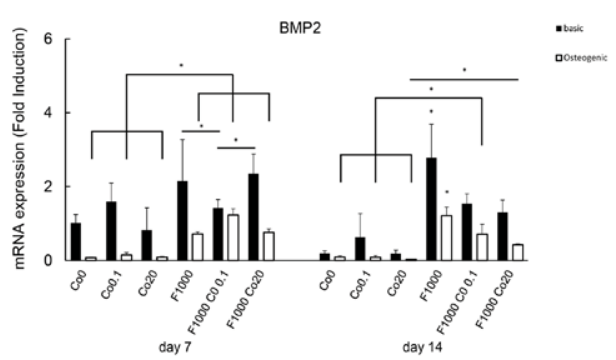

a4

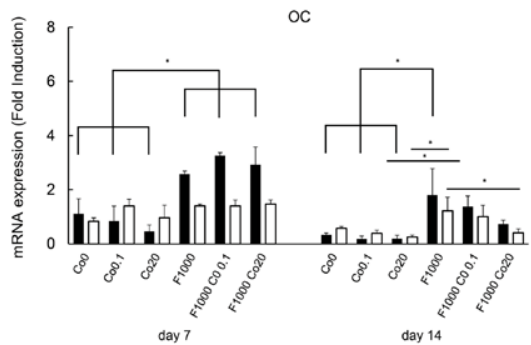

a5

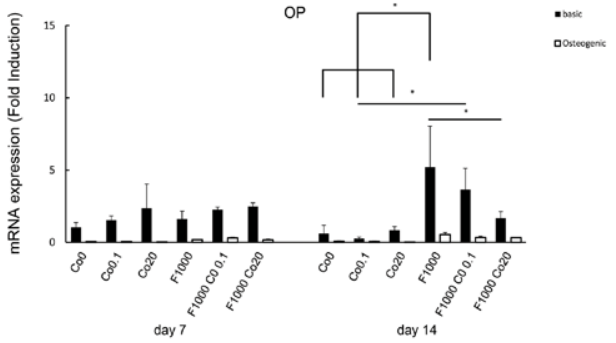

b1

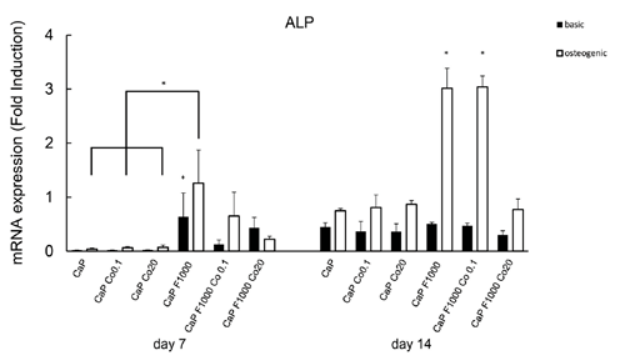

b2

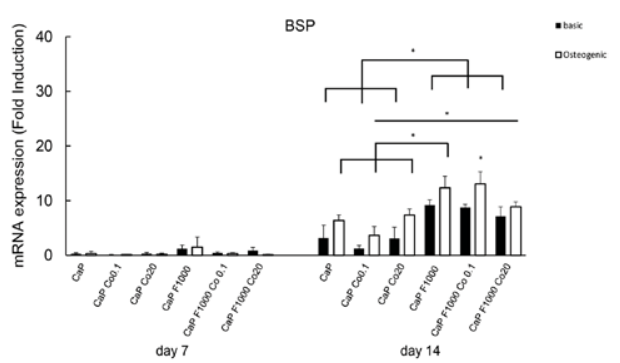

b3

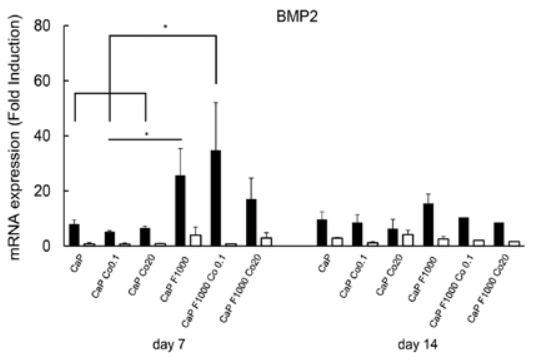

b4

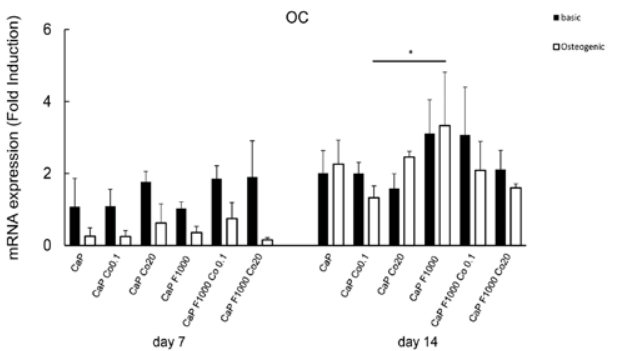

b5

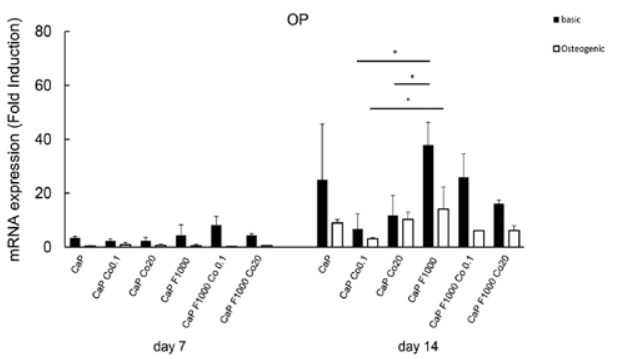

Figure 5. mRNA expression of $\operatorname{ALP}(\mathrm{a} 1, \mathrm{~b} 1), \mathrm{BSP}(\mathrm{a} 2, \mathrm{~b} 2), \mathrm{BMP} 2(\mathrm{a} 3, \mathrm{~b} 3), \mathrm{OC}(\mathrm{a} 4, \mathrm{~b} 4)$ and OP (a5, b5) in hMSCs $(n=3)$ cultured on uncoated tissue culture plastic and on CaP coatings, respectively. Limited to no effect of $\mathrm{Co}^{2+}$ was detected on the expression of osteogenic genes. In contrast, introduction of $\mathrm{F}^{-}$ions to hMSCs in general substantially promoted the expression of osteogenic genes. Combined supplementation/incorporation of both ions had a less stimulatory effect on osteogenic differentiation than the use of $\mathrm{F}^{-}$ions alone.

was quantified via qPCR analysis after 7 and $14 \mathrm{~d}$ of culture (figure 5).

Addition of $\mathrm{Co}^{2+}$ ions to cell culture medium resulted in a dose-dependent reduction of ALP expression, independent of medium and time point. Addition of $\mathrm{F}^{-}$to cell medium, however, strongly enhanced expression of ALP at all the time points, the effect which was more pronounced in osteogenic medium. Combination of dissolved $\mathrm{Co}^{2+}$ and $\mathrm{F}^{-}$ions decreased ALP expression when compared to addition of $\mathrm{F}^{-}$ions alone, however, the expression of ALP was still significantly higher compared to control and $\mathrm{Co}^{2+}$-added samples (figure 5(a1)). 


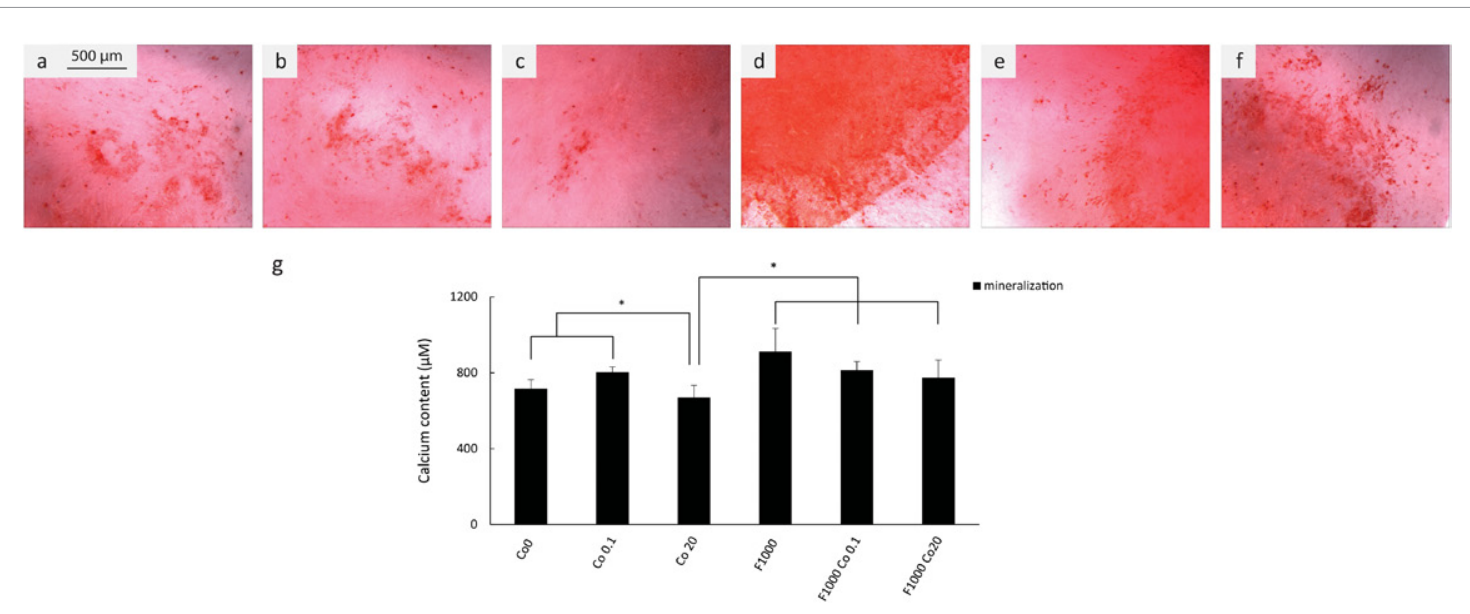

Figure 6. Light microscopy images of mineral formation by hMSCs $(n=3)$ cultured in mineralization medium without supplements (a) and with $0.1 \mu \mathrm{M} \mathrm{Co}^{2+}$ (b), $20 \mu \mathrm{M} \mathrm{Co}^{2+}$ (c), $1000 \mu \mathrm{M} \mathrm{F}^{-}$(d), $1000 \mu \mathrm{M} \mathrm{F}^{-}$and $0.1 \mu \mathrm{M} \mathrm{Co}^{2+}$ (e) and $1000 \mu \mathrm{M} \mathrm{F}^{-}$and $20 \mu \mathrm{M} \mathrm{Co}^{2+}$ (f), and quantification of calcium content in the cultures at day $21(\mathrm{~g})$. Presence of $\mathrm{Co}^{2+}$ ions reduced the amount of mineralization in the cultures, however, addition of $\mathrm{F}^{-}$ions, individually or in combination with $\mathrm{Co}^{2+}$ ions, enhanced the mineralization of hMSCs.
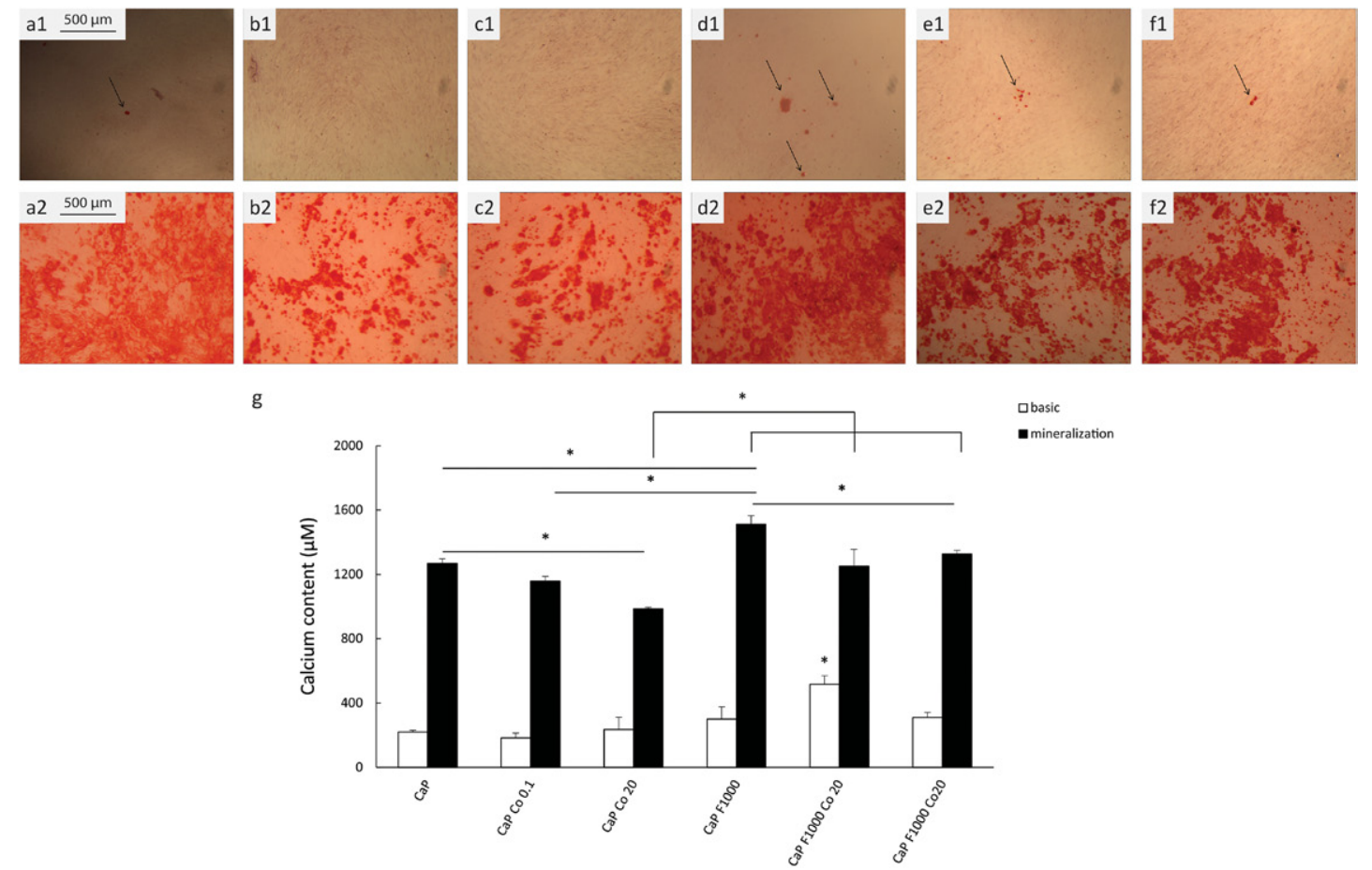

Figure 7. Mineralization of hMSCs $(n=2)$ in basic (a1-f1) and mineralization medium (a2-f2) in a trans-well set-up in the presence of $\mathrm{CaP}$ coating prepared without and with $0.1 \mu \mathrm{M} \mathrm{Co}^{2+}, 20 \mu \mathrm{M} \mathrm{Co}^{2+}, 1000 \mu \mathrm{M} \mathrm{F}^{-}, 1000 \mu \mathrm{M} \mathrm{F}^{-}$and $0.1 \mu \mathrm{M} \mathrm{Co}^{2+}$ and 1000 $\mu \mathrm{M} \mathrm{F}^{-}$and $20 \mu \mathrm{M} \mathrm{Co}^{2+}$, respectively, and quantification of calcium content in the cultures at day 21 (g). In mineralization medium, while presence of $\mathrm{Co}^{2+}$ in the coatings decreased the mineralized area in the coatings, incorporation of $\mathrm{F}^{-}$ions in the coatings resulted in larger mineralization areas and higher calcium content in the cultures.

Also in the CaP coating group, it was generally observed that expression of ALP in hMSCs cultured on $\mathrm{F}^{-}$-incorporated $\mathrm{CaP}$ coatings was higher than on $\mathrm{CaP}$ and $\mathrm{Co}^{2+}$-incorporated $\mathrm{CaP}$ coatings, with this effect being stronger in osteogenic than in basic medium. Addition of $\mathrm{Co}^{2+}$ decreased the positive effect on $\mathrm{F}^{-}$in a dose dependent manner (figure 5(b1)).

Similar to the ALP expression, BSP gene was also upregulated when $\mathrm{F}^{-}$ions, individually or in combination with $\mathrm{Co}^{2+}$ ions, were added to cell media at both time points. Addition of $\mathrm{Co}^{2+}$ to $\mathrm{F}^{-}$inhibited some- what its effect in a dose dependent manner, though not to the level of the control medium without additives (figure 5(a2)).

In the $\mathrm{CaP}$ group, no significant differences were detected in the expression of BSP gene among different samples at day 7 . At day $14, \mathrm{~F}^{-}$-incorporated $\mathrm{CaP}$ coatings generally led to a higher BSP expression in both media as compared to coatings without or with only $\mathrm{Co}^{2+}$ and the adverse effect of the addition of $\mathrm{Co}^{2+}$ was only seen at higher concentration and only in osteogenic medium (figure 5(b2)). 
Regarding BMP2 expression by cells cultured in ionconditioned media, no significant effect among different conditions was observed at day 7 in basic medium. However, in osteogenic medium at day 7 and in both media at day 14 , supplementation by $\mathrm{F}^{-}$ions resulted in a higher BMP2 expression, as compared to control media, or media containing only $\mathrm{Co}^{2+}$. A decrease in the BMP2 expression was observed in combined ion condition as compared to the condition with $\mathrm{F}^{-}$only (figure 5(a3)).

Also on CaP coatings, a positive effect of $\mathrm{F}^{-}$incorporation was observed on the BMP2 expression, with significant differences between CaP F1000 and $\mathrm{CaP}$ Co0.1 and between CaP F1000 Co0.1 and $\mathrm{CaP}, \mathrm{CaP} \mathrm{Co} 0.1$ and $\mathrm{CaP} \mathrm{Co} 20$ in basic medium at $7 \mathrm{~d}$ (figure 5(b3)).

OC expression by cells cultured on uncoated and on coated tissue culture plastic remained relatively low for all conditions. All $\mathrm{F}^{-}$supplemented basic media significantly increased OC gene expression compared to control basic medium and $\mathrm{Co}^{2+}$ supplemented media at $7 \mathrm{~d}$. At day 14, the $\mathrm{F}^{-}$-supplemented media showed a positive effect on OC expression, as compared to the conditions without $\mathrm{F}^{-}$, in both types of media. A decrease in the expression was observed upon addition of $\mathrm{Co}^{2+}$ to $\mathrm{F}^{-}$conditioned medium, in particular at higher concentrations (figure 5(a4)).

The effect of ion supplementation of the CaP coating on the OC expression was relatively small, with the only significant difference being between CaP F1000 and $\mathrm{CaP} \mathrm{Co} 0.1$ in osteogenic medium at $14 \mathrm{~d}$ of culture (figure 5(b4)).

While no significant differences were detected in the expression of OP at day 7 among different conditions, at day 14 , a general trend was that addition of $\mathrm{F}^{-}$individually or in combination with $\mathrm{Co}^{2+}$ ions increased $\mathrm{OP}$ expression compared to the other samples. This effect was observed in both media even though the expression of OP was lower in osteogenic medium. Combining $\mathrm{Co}^{2+}$ ions with $\mathrm{F}^{-}$ions reduced the expression of $\mathrm{OP}$, dose-dependently. However, even in the highest concentration of $\mathrm{Co}^{2+}$, this combination led to higher OP expression compared to the control samples, as well as when $\mathrm{Co}^{2+}$ ions were added individually (figure 5(a5)).

Also in the case of cells cultured on CaP coatings, at day 14 , a beneficial effect of $\mathrm{F}^{-}$incorporation was observed, in particular as compared to the coatings where only $\mathrm{Co}^{2+}$ was incorporated (figure 5(b5)).

\section{Effect of $\mathrm{Co}^{2+}$ and $\mathrm{F}^{-}$on hMSC mineralization}

Mineralization of hMSCs cultured on tissue culture plastic in basic or mineralization medium supplemented with $\mathrm{Co}^{2+}$ and/or $\mathrm{F}^{-}$and on $\mathrm{CaP}$ coated tissue culture plastic without and with ion incorporation in basic and mineralization medium was analyzed after a $21 \mathrm{~d}$ culture period by staining the cells with Alizarin red solution.

When cultured on uncoated tissue culture plastic, hMSCs did not show any signs of mineralization in basic medium (data not shown). However, mineralization of the cells cultured in mineralization medium was detected (figures 6(a)-(f)). Supplementing the medium with $20 \mu \mathrm{M} \mathrm{Co}^{2+}$ reduced the visible mineralized area (figures $6(\mathrm{a})-(\mathrm{c})$ ), while the mineralized area was increased when the cells were exposed to 1000 $\mu \mathrm{M} \mathrm{F}^{-}$ions (figure $6(\mathrm{~d})$ ). Although the combination of $\mathrm{Co}^{2+}$ and $\mathrm{F}^{-}$ions showed less pronounced mineralization compared to the condition where only $\mathrm{F}^{-}$ions were added, they resulted in a mineralization comparable to that observed in the control medium and medium supplemented with $0.1 \mu \mathrm{M}$ Co (figures 6(e) and(f)). Calcium content quantification confirmed these results, however, the differences were relatively small and the only significant difference was found between F1000 and Co20 condition (figure 6(g)).

Since Alizarin red staining of cells cultured on $\mathrm{CaP}$ coatings does not allow reliable quantification of cell mineralization, the culture was also performed in a trans-well set up in which the cells were cultured on the surface of the well while sharing a medium with a CaPcoated cover slip placed in the inset of the trans-well.

The culture in basic medium did not result in a high amount of mineralization. Small nodules of mineralization were, however, detected in hMSCs cultured with $\mathrm{CaP}$ coatings as shown by arrows in figure 7 (a1). Mineralization nodules did not form when cells were cultured with $\mathrm{Co}^{2+}$-incorporated $\mathrm{CaP}$ coatings (figures 7(b1)(c1)). When cultured with $\mathrm{F}^{-}$-incorporated and $\mathrm{F}^{-}$and $\mathrm{Co}^{2+}$-incorporated $\mathrm{CaP}$ coatings, the mineralization nodules were found in larger numbers, however, they did not grow into mineralized areas (figures $7(\mathrm{~d} 1)-(\mathrm{fl})$ ). Quantification of the mineralization showed a slight increase in the calcium level in $\mathrm{F}^{-}$containing coatings compared to the coatings without $\mathrm{F}^{-}$incorporation (figure $7(\mathrm{~g})$ ).

In mineralization medium, cells cultured with $\mathrm{CaP}$ coatings showed extensive mineralization (figures 7(a2)-(f2)). In CaP Co0.1 and CaP Co20 coatings, the nodules were observed, however, they appeared dispersed over the surface (figures 7(b2)-(c2)). In contrast, in CaP F1000 samples, larger dense mineralization areas were observed (figure $7(\mathrm{~d} 2)$ ). The density of the mineralized layer reduced upon addition of both $\mathrm{Co}^{2+}$ and $\mathrm{F}^{-}$ions into the coating as compared to the coating only containing $\mathrm{F}$, but the mineralized area was still larger than in the CaP Co0.1 and CaP Co20 condition (figures 7(e2) and (f2)). Quantification of calcium content in the cultures showed that indeed F-incorporated $\mathrm{CaP}$ coatings resulted in higher calcium levels compared to $\mathrm{CaP}$ coatings with $\mathrm{Co}^{2+}$ incorporation (figure $7(\mathrm{~g})$ ).

\section{Discussion}

The current use of bioinorganics in the field of orthopedics and dentistry ranges from antiosteoporotic and anti-cariogenic treatments, to their incorporation into bone graft substitutes, with the 
aim of improving the properties and performance of the latter. As single trace elements incorporated into synthetic materials have demonstrated positive results to date, incorporating multiple bioinorganics may further enhance the biological performance. Several attempts have been made to incorporate multiple bioinorganics into various $\mathrm{CaP}$-based materials [39-45], revealing enhanced impact of multiple bioinorganics on bone formation processes. In the present study, we have investigated the combined effect of $\mathrm{Co}^{2+}$ and $\mathrm{F}^{-}$ions, which have been suggested to positively influence angiogenesis and osteogenesis, respectively.

For $\mathrm{Co}^{2+}$, a low $(0.1 \mu \mathrm{M})$ and a higher $(20 \mu \mathrm{M})$ concentration were used, above which cytotoxic effects of the ion were reported [11].A constant $\mathrm{F}^{-}$concentration of $1000 \mu \mathrm{M}$ was selected based on a preliminary study, at which the strongest positive effect on ALP activity of hMSCs was observed (data not shown), while avoiding cytotoxicity that has been reported above this concentration range $[20,21]$. In parallel with studies on direct ions supplementation of the cell culture medium, the ions were incorporated into a CaP coating using a previously described method [32]. Similar concentrations of cobalt and fluoride salts were used as described for direct medium supplementation, without issues with stability of the $\mathrm{CaP}$ solution. However, since the efficiency of incorporation is never $100 \%$, it should be noted that the amount of ions presented to the cells upon culture on $\mathrm{CaP}$ coatings is always lower than that achieved through direct supplementation of the medium. Furthermore, the concentrations selected in this study were optimized for in vitro experiments and the optimal ion content in the coatings may be different in the in vivo situation.

Physico-chemical characterization of the coatings revealed homogenous deposition of a low-crystalline $\mathrm{CaP}$ that predominantly consisted of an OCP phase with incorporation of some carbonate, which is in accordance with results previously obtained by applying the same technique $[36,37]$. Within the applied concentration range, the addition of $\mathrm{Co}^{2+}$ ions did not have an apparent effect on $\mathrm{CaP}$ coating properties, confirming the data previously presented by Patntirapong et al [15]. Conversely, when $\mathrm{F}^{-}$ions were added to the coating solution, significant changes were observed in the morphology of the CaP crystals, decreasing in size and becoming more rod-shaped as shown in previous studies [32, 46-48], which is closer to apatitic crystal morphology [32]. This observation was confirmed by the changes observed in FTIR spectra after $\mathrm{F}^{-}$incorporation.

The effect of $\mathrm{Co}^{2+}$ on the expression of angiogenic markers was measured as a first test to determine whether this ion could aid angiogenesis in a bone graft substitute. Vascularization is critical for the process of bone formation and remodeling, both in the development stage and during repair $[49,50]$. The absence of adequate blood supply, for example, in critically sized bone defects, may result in pathological conditions during the bone formation process.

The addition of $\mathrm{Co}^{2+}$ ions, both as direct supplement to the medium or incorporated into CaP coatings, upregulated the expression of VEGF and CD31 in hMSCs as compared to the control without $\mathrm{Co}^{2+}$, although, in general, the expression of these markers was relatively low. A low expression of CD31 of hMSCs cultured in basic or osteogenic medium was expected based on an earlier study [51]. Higher marker expression was found when $\mathrm{Co}^{2+}$ was added to cell medium as a dissolved salt, which may be due to differences in concentration. These results are in accordance with those previously reported in literature. Supplementation of $\mathrm{Co}^{2+}$ ions in cell medium as well as the release of $\mathrm{Co}^{2+}$ from bioactive glass was shown to result in a significant increase in VEGF gene expression and/or protein release $[14,17]$. Furthermore, the implantation of $\mathrm{Co}^{2+}$-treated cells seeded on a collagen scaffold resulted in enhanced vascularized bone formation [17]. Cobalt, in ionic form, has been shown to induce hypoxia conditions by directly binding to and stabilizing hypoxia inducible factor- $\alpha[16,17]$. Cells compensate for the low oxygen levels by expressing angiogenic markers and increasing blood vessel formation, which is the suggested mechanism behind the positive effect of $\mathrm{Co}^{2+}$ ions on angiogenesis [2].

The addition of $\mathrm{Co}^{2+}$ ions did not significantly change the DNA content of the cells. As DNA content can be considered an indication of cell number and growth, this result indicated that the presence of $\mathrm{Co}^{2+}$ ions did not have adverse effects on the cell viability. Although the toxic effects of $\mathrm{Co}^{2+}$ on various cell types have been reported, these effects were substantially dependent on the locally delivered dose, as well as the cell type [11-14].

The addition of $1000 \mu \mathrm{M} \mathrm{F}^{-}$ions to cell medium did not appear to affect the DNA content of the cells at day 7 either. However, at day 14 , there was a small increase in the DNA content compared to control and $\mathrm{Co}^{2+}$ -containing samples. Previous studies, however, have reported opposing results using similar concentrations of $\mathrm{F}^{-}$ions, emphasizing different responses depending on the cell type [20,21].

While no effect was observed on the DNA content upon direct addition of $\mathrm{F}^{-}$to the cell culture medium, incorporation into $\mathrm{CaP}$ coatings generally resulted in a reduction of the DNA content of the cells at later time points compared to $\mathrm{CaP}$ and $\mathrm{Co}^{2+}$-incorporated $\mathrm{CaP}$. This effect is possibly a result of the change of CaP coating morphology upon $\mathrm{F}^{-}$ions incorporation.

Regarding the effect on the osteogenic differentiation of hMSCs, $\mathrm{Co}^{2+}$ ions suppressed the ALP enzymatic activity as well as the ALP expression at mRNA level, with the effect being more pronounced with direct addition to cell medium condition compared to the incorporation into the $\mathrm{CaP}$ coating, possibly due to differences in concentrations. Similar results were found for the expression of BSP gene, whereas no strong 
effect was found on the expression of BMP2, OC and OP using either delivery method. ALP and BSP genes are directly related to mineralization of the cells $[52,53]$ and it was therefore not surprising to observe that direct addition, as well as incorporation of $\mathrm{Co}^{2+}$, reduced the mineralization of hMSCs in terms of number and size of mineralization nodules and calcium content. These findings are consistent with earlier studies on the effect of cobalt on the osteogenic differentiation of osteoblastic progenitor and ligament cells. Andrews et al [11] also observed a reduction in ALP activity of SaOS-2 cells upon $\mathrm{Co}^{2+}$ supplementation at concentrations higher than $10 \mu \mathrm{M}$, and attributed this effect to the potential cytotoxicity of the ions observed at these concentrations. Our data, however, did not show a reduction in cell proliferation in the examined range of concentrations. Similarly, Osathanon et al [13] reported reduced ALP activity and expression of osteogenic genes including ALP, OC and RUNX2 as well as a significant reduction in mineralization in human periodontal ligament cells when cultured with 50 and $100 \mu \mathrm{M} \mathrm{CoCl}_{2}$. These effects were attributed to the ability of $\mathrm{Co}^{2+}$ ions to maintain the stemness of the cells.

Exposure of hMSCs to $\mathrm{F}^{-}$ions resulted in a strong increase in ALP activity, expression of osteogenic markers at mRNA level, as well as the formation and growth of mineralization nodules. Similar results have been previously obtained for both studies with and without CaP materials [20-22, 24, 26-29, 31-33]. Several mechanisms have been proposed to describe the effects of fluoride on bone cells, in which many proteins and signaling pathways are involved [54]. The effects are, however, commonly attributed to fluoride's anabolic role on bone metabolism which increases the proliferation of bone cells, in addition to its potential in stimulating osteogenic differentiation, resulting in the deposition of bone matrix [21,22]. Besides these direct effect, the change of crystal morphology upon incorporation of $\mathrm{F}^{-}$ions into the $\mathrm{CaP}$ coatings may also affect the osteogenic differentiation, as has been previously proposed by Yang et al [32]. Regardless of the mechanism, these results support the use of $\mathrm{F}^{-}$ions as means to enhance osteogenic differentiation of hMSCs.

Regarding the effect of the combination of the two ions on proliferation, osteogenic differentiation and mineralization of hMSCs, the general trend observed was that the addition of $\mathrm{Co}^{2+}$ weakened the positive effect of $\mathrm{F}^{-}$ions, independent of the method of delivery. Nevertheless, even at higher $\mathrm{Co}^{2+}$ concentrations, a combination of the two ions indicated a more pronounced osteogenic differentiation and mineralization than the control without ionic additives.

While $\mathrm{Co}^{2+}$ and $\mathrm{F}^{-}$release into cell culture medium has not been quantified in this study, in an earlier study, the effect of $\mathrm{Co}^{2+}$ ions incorporated into similar $\mathrm{CaP}$ coatings as used here was studied on osteoclastic resorption. In this study a gradual release of $\mathrm{Co}^{2+}$ into cell culture medium was observed over a $9 \mathrm{~d}$ culture period [15]. Similarly, we have observed the release of
$\mathrm{Sr}^{2+}$ from similar CaP coatings into cell culture medium (unpublished data). Therefore, it is assumed that both $\mathrm{Co}^{2+}$ and $\mathrm{F}^{-}$were released into the cell culture medium during culture of hMSCs here. This is in contrast to calcium $\left(\mathrm{Ca}^{2+}\right)$ and inorganic phosphate $(\mathrm{Pi})$ ions, which are actually taken up from the medium, probably as a result of their high concentration in the medium. Clearly, the dynamics of this ion exchange on the surface in complex and requires further investigation.

While our results suggest that $\mathrm{Co}^{2+}$ ions promote the expression of angiogenic markers by hMSCs, and that $\mathrm{F}^{-}$alone and in combination with $\mathrm{Co}^{2+}$ favors osteogenesis, further investigation is needed to confirm that the combination is also beneficial for angiogenesis. While enhanced expression of VEGF has been reported in rats upon treatment with $\mathrm{F}^{-}[55,56]$, the possibility of some antagonistic effects on vascularization from the combination of $\mathrm{Co}^{2+}$ and $\mathrm{F}^{-}$remains, and further investigation is justified.

\section{Conclusion}

This study investigated the combined effects of two bioinorganics, $\mathrm{Co}^{2+}$ and $\mathrm{F}^{-}$ions, as a means to stimulate both angiogenesis and osteogenesis. While $\mathrm{Co}^{2+}$ can stimulate angiogenesis, its detrimental effects on osteogenesis can be overruled by the addition of $\mathrm{F}^{-}$. The combination of $\mathrm{Co}^{2+}$ and $\mathrm{F}^{-}$ resulted in higher expression of osteogenic markers and mineralization compared to the controls without ionic additives. This effect was obtained by direct addition of the ions to the cell culture medium, as well as through incorporation into CaP. Such approaches can be used to improve the performance of the bone graft substitutes.

\section{Acknowledgments}

This research forms part of the Project P2.04 BONEIP of the research program of the BioMedical Materials institute, co-funded by the Dutch Ministry of Economic Affairs, Agriculture and Innovation. PH acknowledges The Netherlands Science Organization (NWO) for financial support (Aspasia premium number 015.008.039). This research has been in part made possible with the support of the Dutch Province of Limburg.

\section{References}

[1] Bose S and Tarafder S 2012 Acta Biomater. 8 1401-21

[2] Bose S, Fielding G, Tarafder S and Bandyopadhyay A 2013 Trends Biotechnol. 31 594-605

[3] Aaseth J, Boivin G and Andersen O 2012 J. Trace Elem. Med. Biol. 26 149-52

[4] Yang L, Harink B and Habibovic P 2011 Calcium Phosphate Ceramics with Inorganic Additives ed P Ducheyne (Oxford: Elsevier) ch 1.118 pp 229-312

[5] Habibovic P and Barralet J E 2011 Acta Biomater. 7 3013-26

[6] Boanini E, Gazzano M and Bigi A 2010 Acta Biomater. $61882-94$ 
[7] Mourino V, Cattalini J P and Boccaccini A R 2012 J. R. Soc. Interface 9 401-19

[8] Gál J, Hursthouse A, Tatner P, Stewart F and Welton R 2008 Environ. Int. 34 821-38

[9] Chen Q and Thouas G A 2015 Mater. Sci. Eng. R 87 1-57

[10] Simonsen L O, Harbak H and Bennekou P 2012 Sci. Total Environ. 432 210-5

[11] Andrews R E, Shah K M, Wilkinson J M and Gartland A 2011 Bone 49 717-23

[12] Ignjatović N, Ajduković Z, Savić V, Najman S, Mihailović D, Vasiljević P, Stojanović Z, Uskoković V and Uskokovic D 2013 J. Mater. Sci.: Mater. Med. 24 343-54

[13] Osathanon T, Vivatbutsiri P, Sukarawan W, Sriarj W, Pavasant P and Sooampon S 2015 Arch. Oral Biol. 6029-36

[14] Wu C, Zhou Y, Fan W, Han P, Chang J, Yuen J, Zhang M and Xiao Y 2012 Biomaterials 33 2076-85

[15] Patntirapong S, Habibovic P and Hauschka P V 2009 Biomaterials 30 548-55

[16] Yuan Y, Hilliard G, Ferguson T and Millhorn D E 2003 J. Biol. Chem. 178 15911-6

[17] Fan W, Crawford R and Xiao Y 2010 Biomaterials 31 3580-9

[18] Surmenev R A, Surmeneva M A and Ivanova A A 2014 Acta Biomater. 10 557-9

[19] Hattab F N 1989 J. Dent. 17 47-54

[20] Bellows C G, Heersche J N and Aubin JE 1990 J. Bone Miner. Res. 5 101-5

[21] Qu W, Zhong D, Wu P, Wang J and Han B 2008 J. Bone Miner Metab. 26328-34

[22] Hall B K 1987 Bone 8 111-6

[23] Lee E J, Lee S H, Kim H W, Kong Y M and Kim H E 2005 Biomaterials $263843-51$

[24] Wang Y S, Zhang S, Zeng X T, Ma L L, Weng W J and Yan W Q 2007 Acta Biomater. 3 191-7

[25] Sam Z, Zeng X T, Wang Y S, Cheng K L and Wenig W J 2006 Surf. Coat. Technol. 200 6350-4

[26] Hahn B, Cho Y, Park D, Choi J, Ryu J, Kim J, Ahn C, Park C, Kim H and Kim S 2011 J. Biomater. Appl. 27 587-94

[27] Wang J, Chao Y, Wan Q, Zhu Z and Yu H 2009 Acta Biomater. 5 1798-807

[28] Kim H, Kim H and Knowles J C 2004 Biomaterials $253351-8$

[29] Li J, Song Y, Zhang S, Zhao C, Zhang F, Zhang X, Cao L, Fan Q and Tang T 2010 Biomaterials 31 5782-8

[30] Kim H, Kong Y, Bae C, Noh Y and Kim H 2004 Biomaterials 25 2919-26

[31] Qu H and Wei M 2006 Acta Biomater. 2 113-9
[32] Yang L, Perez-Amodio S, Barre` re-de Groot FY F, Everts V, van Blitterswijk CA and Habibovic P 2010 Biomaterials 31 2976-89

[33] Gentleman E, Stevens M M, Hill R G and Brauer D S 2013 Acta Biomater. 95771-9

[34] Fernandes H, Mentink A, Bank R, Stoop R, van Blitterswijk C and de Boer J 2010 Tissue Eng. A 16 1693-702

[35] Both S K, van der Muijsenberg A J C, van Blitterswijk C A, de Boer J and de Bruijn J D 2007 Tissue Eng. 13 3-9

[36] Habibovic P, Li J, van der Valk C M, Meijer G, Layrolle P, van Blitterswijk C A and de Groot K 2005 Biomaterials 26 23-36

[37] Barrère F, Layrolle P, van Blitterswijk C A and de Groot K 1999 Bone 25 107S-11S

[38] Hench L L and Best S M 2013 Ceramic, Glasses and Glass Ceramics: Basic Principles 3rd edn ed B D Ratner (New York: Academic) ch I.2.4 pp 128-51

[39] Sadera M S, Lewis K, Soares G A and LeGeros R Z 2013 Mater. Res. 16 779-84

[40] Yao F, LeGeros R Z 2010 Mater. Sci. Eng. C 30 423-30

[41] Badraoui B, Aissa A, Bigi A, Debbabi M and Gazzano M 2009 Mater. Res. Bull. 44522-30

[42] Roy M, Fielding G A, Bandyopadhyay A and Bose S 2013 Biomater. Sci. 1 74-82

[43] Tarafder S, Davies N M, Bandyopadhyay A and Bose S 2013 Biomater. Sci. 1 1250-9

[44] Fielding G and Bose S 2013 Acta Biomater. 9 9137-48

[45] Bose S, Tarafder S, Banerjee S S, Davies N M and Bandyopadhyay A 2011 Bone 48 1282-90

[46] Shiwaku Y, Anada T, Yamazaki H, Honda Y, Morimoto S, Sasaki K and Suzuki O 2012 Acta Biomater. 84417-25

[47] Xia W, Lindahl C, Persson C, Thomsen P, Lausmaa J and Engqvist H 2010 J. Biomater. Nanobiotechnol. 1 7-16

[48] Fan Y, Sun Z and Moradian-Oldak J 2009 Caries Res. 43 32-136

[49] Gerber H and Ferrara N 2000 Trends Cardiovasc. Med. $10223-8$

[50] Carano R A D and Filvaroff E H 2003 Drug Discovery Today 8980-9

[51] Rouwkema J, de Boer J, van Blitterswijk C A 2006 Tissue Eng. 12 2685-93

[52] Orimo H 2010 J. Nippon Med. Sch. 77 4-12

[53] Gordon J A R, Tye C E, Sampaio A V, Underhill T M, Hunter G K and Goldberg H A 200741 462-73

[54] Lau K H W and Baylink D J 1998 J. Bone Miner. Res. 13 1660-7

[55] Liu G, Zhang W, Jiang P, Li X, Liu C and Chai C 2012 Environ. Toxicol. Pharmacol. 34 209-17

[56] Alhijazi A Y and Dheyaa Neamah A 2014 Int. Res. J. Nat. Sci. 252-68 